\title{
TINJAUAN YURIDIS TENTANG HAK MILIK YANG DIGUNAKAN OLEH NEGARA UNTUK KEPENTINGAN UMUM
}

\author{
SJAIFURRACHMAN \\ Fakultas Hukum, Universitas Wiraraja Sumenep \\ sjafurrachman@yahoo.com \\ ABSHORIL FITHRY \\ Fakultas Hukum, Universitas Wiraraja Sumenep \\ abshorilfithry@ rocketmail.com
}

\begin{abstract}
ABSTRAK
Penelitian ini dilakukan untuk mendapatkan gambaran tentang Mekanisme dalam Pelepasan Tanah Untuk Kepentingan Umum. Mekanisme yang dituangkan dalam UndangUndang No.2 Tahun 2012 tentang pengadaan tanah bagi pembangunan untuk kepentingan umum berbeda dengan mekanisme yang di atur dalam KUH Perdata, di mana dalam KUH Perdata mekanisme dapat dilakukan jika sebelumnya terdapat hubungan hukum antara para pihak. Sedangkan mekanisme yang diterapkan disaat kesepakatan antara para pihak tidak tercapai, tidak ada hubungan hukum sama sekali diantara para pihak tersebut. Dari uraian latar belakang diatas maka Permasalahan yang diangkat dalam penelitian ini Bagaimana prosedur pelepasan hak milik atas tanah yang dilakukan oleh Pemerintah untuk kepentingan umum dan Bagaimana penyelesaian hukum yang dapat dilakukan oleh Pemerintah jika terjadi sengketa dalam pelepasan hak milik atas tanah untuk kepentingan umum. Tujuan yang hendak dicapai untuk mengetahui dan menganalisa prosedur pelepasan hak milik atas tanah yang dilakukan oleh Pemerintah untuk kepentingan umum dan untuk mengetahui dan menganalisa upaya penyelesaian hukum yang dapat dilakukan oleh Pemerintah jika terjadi sengketa dalam pelepasan hak milik atas tanah untuk kepentingan umum.
\end{abstract}

Kata kunci: Konsinyasi, Pengadaan Tanah, Kepentingan Umum.

\section{A. PENDAHULUAN}

Tanah berfungsi sangat strategis dalam memenuhi kebutuhan negara dan rakyat yang semakin beragam dan meningkat. "Tanah merupakan bagian dari bumi, yang disebut permukaan bumi”. Meningkatnya kebutuhan masyarakat akan tanah, bahkan mendorong meningkatnya kegiatan jual beli tanah sebagai salah satu bentuk proses peralihan hak atas tanah. Artinya yang dimaksud dengan peralihan di sini adalah perbuatan hukum yang sengaja dilakukan dengan tujuan agar hak atas tanah berpindah dari yang mengalihkan kepada yang menerima pengalihan.

Pada Negara-negara agraris seperti Indonesia, tanah merupakan faktor produksi sangat penting karena menentukan kesejahteraan hidup penduduk negara bersangkutan. Paling sedikit ada tiga kebutuhan dasar manusia yang tergantung pada tanah. Pertama, tanah sebagai sumber ekonomi guna kehidupan. Kedua, tanah sebagai tempat mendirikan rumah untuk tempat tinggal. Ketiga, tanah sebagai kuburan.

Setiap pembangunan sangat di butuhkan keberadaan tanah. Tanah adalah modal dasar 
pembangunan. Hampir tak ada kegiatan pembangunan yang tidak memerlukan tanah. Tanah memegang peranan yang sangat penting, bahkan menentukan berhasil tidaknya dari pembangunan.

Pada Pasal 1 Ayat (2) Undang-Undang Nomor 5 Tahun 1960 tentang Peraturan Dasar Pokok-Pokok Agraria (selanjutnya disebut UUPA), yaitu "Bumi, air dan ruang angkasa, serta segala kekayaan alam yang terkandung di dalamnya adalah merupakan karunia yang diberikan Tuhan kepada umat manusia". Hubungan antara manusia dengan bumi sangat erat kaitannya dengan hak dan kewajiban manusia dalam memanfatkan penguasaannya. Hubungan itu tercermin dalam penguasaan, kepemilikan hak atas tanah.

Pasal 14 UUPA menetapkan agar Pemerintah dan Pemerintah Daerah membuat suatu rencana umum mengenai persediaan, peruntukan dan penggunaan bumu, air,ruang angkasa dan kekayaan alam yang terkandung di dalamnya untuk

1. Kepentingan yang bersifat politis, Termasuk kepentingan yang bersifat politis misalnya perkantoran Pemerintah atau Pemerintah Daerah, Pertanahan dan Keamanan.

2. Kepentingan yang bersifat ekonomis, Termasuk kepentingan yang bersifat ekeonomis,misalnya tanah untuk pengembangan pertanian, perikanan, peternakan, pekerbunan,industri, pertokoan, perdagangan, kehutanan, pertambangan.

3. Kepentingan yang bersifat sosial dan keagamaan . Termasuk kepentingan yang bersifat sosial dan keagamaan, yaitu tanah untuk keperluan perumahan, peribadatan,makam, pendidikan, rekreasi.

Secara konstitusional, Undang-Undang Dasar 1945 dalam Pasal 33 Ayat (3) telah memberikan landasan bahwa bumi dan air serta kekayaan alam yang terkandung di dalamnya dikuasai oleh Negara dan dipergunakan untuk sebesar-besarnya kemakmuran rakyat.

Undang-Undang Pokok Agraria menyatakan bahwa Negara berhak menguasai bumi, air dan ruang angkasa yang termuat dalam ketentuan Pasal 2 Ayat (1) UUPA menyatakan bahwa "bumi, air dan ruang angkasa, termasuk kekayaan alam yang terkandung didalamnya itu pada tingkatan tertinggi dikuasai oleh Negara, sebagai organisasi kekuasaan seluruh rakyat"

Guna memberikan kepastian hukum kepada para pemegang hak atas tanah, dalam Pasal 32 Ayat (2) Peraturan Pemerintah Nomor 24 Tahun 1997 tentang Pendaftaran Tanah (selanjutnya disebut PP Pendaftaran Tanah), telah ditegaskan bahwa sertifikat merupakan alat bukti yang kuat, sebagai orang tidak menuntut tanah yang sudah bersertifikat atas nama orang atau badan hukum.

Sebagai salah satu contoh kasus terkait dengan kepemilikan hak atas tanah terjadi di 
daerah Kecamatan Kalianget, Kabupaten Sumenep banyak sengketa yang terjadi atas petani termasuk yang terkait sengketa tanah pegaraman dengan intensitas lebih tinggi dan menjadi pusat perlawanan petani. Munculnya berbagai organisasi petani garam seperti Yayasan Tanah Leluhur (YTL) dan Yayasan AL-Jihad. Pada awalnya tanah pada PT Garam (Persero) (Persero) tersebut milik masyarakat. Keberadaan PT Garam (Persero) terletak di daerah pinggirpapas. Dulu pemilik lahan yang di buat untuk penggaraman di desa Desa Pinggirpapas awalnya dimilik oleh Anggasuto sebagai penemu garam pertama kali di Madura. Anggasuto mendapat hibah tanah dari raja Sumenep yakni Pangeran Lor. Pada masa Bupati Sumenep, Kanjeng Samadikun bersama dengan kepala Desa Pinggirpapas yakni Sastro Wijoyo Tahun 1936 melakukan perjanjian 50 (lima puluh) tahun berbahasa Jawa Kuno yang mewakili petani garam menyerahkan tanah pegaraman kepada Belanda.

Sisi historisnya pada saat itu PT Garam (Persero) memberi ganti rugi pada masyarakat pemilik tanah itu dengan memberi upah berupa golden dan uang, tapi karena PT Garam (Persero) tidak berhasil mengelolahnya, maka masyarakat meminta kembali lahan tersebut mengembalikan tanahnya. Kemudian pada tahun 1975, tanah pegaraman milik petani semakin sempit akibat proyek modernisasi dengan melakukan pembebasan tanah yang diwarnai dengan pemaksaan dan intimidasi-intimidasi tertentu yang membuat lahan tanah masyarakat semakin sempit, sehingga mereka merasa kehidupannya tidak sejahtera. Para pemilik tanah atau petani meminta kepada PT. Garam bahwa hendaknya pengelolaanya diserahkan kepada para petani, tapi tidak mau tanahnya sejengkal pun dikelola oleh masyarakat.

Permasalahan ini terus berlanjut sampai sekarang. Masyarakat petani garam meminta untuk di kembalikan tanahnya. Mereka terus berunjukrasa pada PT Garam (Persero) dengan adanya aliran-aliran jihad yang mendukungnya dan meminta perlindungan pada Gubernur Jatim. Persoalan ini pada dasarnya melibatkan Badan Pertanahan di Sumenep yang ikut andil terkait dengan Tanah yang bersifat lintas sektoral dalam penggunaan tanah untuk itu sengaja mengambil tema magang status kepemilikan hak atas tanah yang sebenarnya dengan adanya permasalahan ini maka dari Badan Pertanahan di Sumenep ikut andil dalam penyelesaian mengenai status kepemilikan hak atas tanah.

\section{B. PEMBAHASAN}

Berdasarkan ketentuan-ketentuan tentang fungsi sosial tanah itu tampak bahwa tanah harus digarap dan tidak boleh ditelantarkan begitu saja yang dalam pemanfaatannya dilarang menggunakan caracara pemerasan, pemerintah mengatur batas pemilikan umum menghendakinya dengan pemberian ganti rugi yang layak dan menurut prosedur yang diatur dengan 
Undang-undang. Politik hukum pertanahan yang seperti ini kemudian melahirkan Undang-Undang tentang Landreform dan UU tentang Onteigening.

Undang-Undang Nomor 21 Tahun 1964 tentang Pengadilan Landrefrom dibuat sebagai konsekuensi adanya ketentuan tentang fungsi sosial tanah yang menghendaki adanya pembatasan maksimal hak milik atas tanah yang boleh dimiliki oleh satu keluarga atau badan hukum. UndangUndang tentang ini berasal dari sebuah Peraturan Pemerintah Pengganti UndangUndang (Perpu) yang kemudian dikuatkan menjadi Undang-Undang yakni UU No. 56/PRP/1960. Undang-Undang ini mengatur 3 (tiga) hal penting tentang ini yaitu 1 (pertama), luas minimal dan maksimal tanah pertanian yang boleh dimiliki/dikuasai oleh seorang WNI atau satu keluarga WNI, 2 (kedua), tanah pertanian yang berada dalam gadai (waktu diundangkannya UU ini), 3 (ketiga), peralihan hak milik atas tanah pertanian. Yang penting untuk saat ini dari Undang-Undang Landreform adalah yang pertama dan ketiga yakni ketentuan batas maksimal dan minimal hak atas tanah dan peralihan hak atas tanah pertanian, sebab yang kedua hanyalah peraturan transisi yang berlaku einmalig untuk mengakhiri pemerasan atas orang-orang yang ketika itu tanahnya digadaikan. Sejauh menyangkut batas maksimal tanah pertanian yang boleh dimiliki UU ini menetukan bahwa untuk daerah tidak padat tanah sawah yang boleh dimiliki adalah 15 (lima belas) hektar, tanah kering 20 (dua puluh) hektar, sedangkan untuk daerah padat dibedakan atas daerah yang kurang padat (dengan batas maksimal sawah 7,5 (tujuh koma lima) hektar, tanah kering 9 (Sembilan) hektar), dan sangat padat (dengan batas maksimal sawah 5 (lima) hektar, tanah kering 6 (enam) hektar).

Ukuran kepadatan menggunakan indikator jumlah penduduk setiap kilometer persegi di tiap kabupeten. Selanjutnya sejauh menyangkut peralihan hak atas tanah pada prinsipnya diatur bahwa pemindahan hak atas tanah pertanian yang akan menyebabkan ada pemilik yang memiliki kurang dari 2 (dua) hektar dilarang kecuali karena pewarisan atas karena pemiliknya memang memiliki tanah pertanian yang luasnya kurang dari 2 (dua) hektar dalam waktu satu tahun menjadi pemilik sendirian atau mengalihkan kepada pihak lain tanpa dipecah-pecah.

Langkah-langkah yang sedang dilaksanakan oleh PT Garam (Persero), baik bersama DPRD dan wakil LSM (KRAN) serta wakil pengunjuk rasa antara lain: Pertemuan antara kuasa hukum bekas pemilik tanah, Komisi E DPRD II Sumenep, dan PT. Garam (persero) dilaksanakan tanggal 16 Juni 1998 di ruang pertemuan DPRD. Tanggal 18 Juni 1998 di PT Garam (Persero) dilakukan pertemuan antara Komisi E DPRD II Sumenep dengan PT Garam (Persero). Tanggal 18 dan 20 Juni 1998 peninjauan lapangan oleh DPRD II Sumenep dan PT 
Garam (Persero) untuk lokasi utara dan selatan.

Tanggal 20 Juli 1998 pertemuan tindak berlanjut hasil kunjungan lapangan. Tanggal 27 Juli 1998 pertemuan di PT Garam (Persero) antara PT Garam (Persero) dan DPRD II Sumenep membahas pemecahan masalah tuntutan sebagian bekas pemilih tanah. PT Garam (Persero) mengemukakan bahwa terhadap tanah yang telah dibebaskan dimasksud tidak mungkin untuk dijual kembali sebagaimana tuntutan para pengunjuk rasa karena tanah bagian selatan tersebut telah dibangun satu kesatuan lahan pegaraman yang dikenal dengan nama proyek Renovasi/Modernisasasi Madura Timur fase I dan II yang saat ini dikenal nama pegaraman I dengan kapasitas produksi pada iklim normal sebesar 150.000 ton/tahun.

Bagian utara masih dalam tahap pengembangan secara bertahap dengan nama proyek renovasi Madura Timur fase III, sehingga lahan tersebut sebagian masih belum termanfaatkan mengingat pengembangan belum selesai dan diperkirakan akan selesai tahun 2001. Terhadap tanah bagian selatan yang tersisa (tidak ikut renovasi) yang saat ini digarap dengan cara bagi hasil/sewa oleh sekelompok penggarap lama atau bekas pemilik tanah yang dibebaskan oleh PN Garam, akan diadakan penataan ulang sehingga diharapkan sebagian tanah tersebut dapat diberikan kepada sebagian pengunjuk rasa dengan cara yang sama seperti penggarap yang lama.
Sedangkan terhadap tanah bagian utara, PT Garam (Persero) rencananya akan memberikan dengan cara yang sama seperti bagian selatan. Dalam pertemuan berikutnya dicoba mengadakan pendekatan keinginan kedua belah pihak yakni menginventarisasi bersama jumlah pemilik dan luas lahan produktif yang dibebaskan oleh PT Garam (Persero). Disamping itu, PT Garam (Persero) juga mengadakan inventarisasi terhadap kemungkinan pengurangan luas lahan dan jumlah lama (terhadap lahan non produktif) yang diharapkan kelebihan ini akan diberikan dengan sistim sewa/bagi hasil kepada pengunjuk rasa untuk memenuhi tuntannya.

Namun, dalam pertemuan terakhir pada tahun 1999 terdapat ketidaksesuaian, karena pihak pengunjuk rasa tetap menuntut agar tanah yang dijual kepada PT Garam (Persero) dikembalikan kepada bekas pemilik, karena tanah-tanah tersebut merupakan satu-satunya lahan mata pencaharian mereka. Tawaran PT Garam (Persero) memberikan lahan non produktif yang telah digarap oleh penggarap lama, tidak bisa diterima karena luasnya terlalu sedikit. Para pengunjuk rasa juga menolak garapan dengan sistim sewa apabila para penuntut mau menerima luas lahan tanah yang disediakan oleh PT Garam (Persero).

Berdasarkan ketentuan-ketentuan tentang fungsi social tanah itu tampak bahwa tanah harus digarap dan tidak boleh ditelantarkan begitu saja yang dalam pemanfaatannya dilarang menggunakan cara-cara pemerasan, pemerintah mengatur batas pemilikan umum 
menghendakinya dengan pemberian gantirugi yang layak dan menurut prosedur yang diatur dengan Undang-undang. Politik hukum pertanahan yang seperti ini kemudian melahirkan Undang-Undang tentang Landreform dan Undang-Undang tentang Onteigening.

Secara prosedural pencabutan hak atas tanah dapat dilakukan melalui acara biasa maupun acara luar biasa. Dengan acara biasa dapat dilakukan dengan Hibah, Sewa Menyewa, Jual Beli, Waris dan Pencabutan Hak karena kepentingan umum, dengan demikian instansi yang memerlukan tanah mengajukan permohonan kepada presiden melalui menteri terkait (sekarang menteri Agraria) melalui gubernur/kepada direktorat agraria (sekarang BPN) setempat dengan disertai alasan-alasan dan rencana peruntukan bagi kepentingan umum, identitas tanah dan yang berhak, serta rencana penampungan orang-orang yang haknya akan dicabut. Kepala BPN setempat kemudian meminta pertimbangan Bupati yang bersangkutan tentang relevansinya bagi kepentingan umum serta rencana penampungan orang-orang yang hak atas tanahnya akan dicabut dan meminta panitia penaksir untuk menaksir harga (ganti rugi) yang layak. Setelah itu Kepala BPN setempat mengajukan permintaan pencabutan kepada Menteri Agraria untuk diteruskan kepada Presiden, dan keputusan Presidenlah yang dapat dijadikan dasar pelaksanaan pencabutan hak. Jika pertimbangan Bupati dan penaksir harga tidak diperoleh oleh Kepala BPN setempat maka Kepala BPN dapat langsung menajukannya kepada Menteri Agaria dan menteri ini dapat langsung mengajukan permohonan kepada Presiden dengan meminta pertimbangan dari Menteri Kehakiman lebih dulu.

Pencabutan hak atas tanah dapat juga dilakukan melalui prosedur luar biasa jika ada alasan yang cukup untuk itu sperti terjadinya wabah penyakit dan timbulnya bencana alam. Dengan acara luar biasa Menteri Agraria dapat langsung mengeluarkan surat keputusan untuk mengizinkan pihak yang berkepentingan menguasai tanah, namun seteleh itu harus segera diikuti dengan Keputusan Presiden tentang "persetujuan" atau "penolakan" Presiden atas pencabutan itu. Jika ternyata Presiden menolak keputusan Menteri Agraria tentang pencabutan tanah itu maka yang berkepentingan harus mengembalikan tanah itu dalam keadaan semula dengan segala benda yang ada diatasnya dan/atau dengan ganti rugi. Jika Presiden menyetujui pencabutan hak atas tanah dan ternyata pemilik semula tidak mau menerima ganti rugi yang ditetapkan maka pemilik tersebut dapat mengajukan banding ke Pengadilan Tinggi setempat yang diberi kompetensi untuk ini sebagai pemutus pada tingkat pertama dan terakhir.

Hasil wawancara penulis dengan pejabat badan pertanahan Sumenep, bahwa 
pelaksanaan ketentuan fungsi sosial di daerah umumnya berjalan dengan baik. dan pada dasarnya apa bila kepentingan umum menghendaki maka pencabutan hak atas tanah selalu dilaksanakan sebagai wujud dari ketentuan Pasal 6 UUPA Nomor 5 Tahun 1960.

Sesuai dengan ketentuan, bahwa pencabutan hak hanya dilakukan untuk kepentingan umum, dan hanya dalam keadaan yang memaksa sebagai jalan yang terakhir, maka walaupun acara pencabutan hak sudah mulai, bahkan sudah ada surat keputusan pencabutan haknya sekalipun jika kemudian dapat dicapai persetujuan dengan yang empunya untuk menyelesaikan persoalannya dengan cara jual beli, tukar menukar, atau pembebasan hak, cara itulah yang akhirnya ditempuh.

Pencabutan hak atas tanah merupakan suatu sarana yang diselenggarakan oleh pemerintah untuk mengambil hak atas tanah warga negara demi kepentingan umum, yang di dalamnya terdapat kepentingan bersama rakyat, kepentingan bangsa dan negara, serta kepentingan pembangunan. Dalam Pasal 1 UU Nomor 20 tahun 1961 tentang Pencabutan Hak-Hak Tanah Dan Benda Yang Ada Di Atas Nya, dinyatakan bahwa "Untuk kepentingan uтит, termasuk kepentingan bangsa dan negara serta kepentingan bersama rakyat, demikian pula kepentingan pembangunan, maka Presiden dalam keadaan memaksa setelah mendenangar menteri agraria, kehaiman dan mentri yang bersangkutan dapat mencabut hak-hak atas tanah dan benda-benda yang ada di atasnya"

Memperhatikan ketentuan yang ada pada Pasal 1 UU nomor 20 tahun 1961 di atas, maka sebelum presiden mengeluarkan keputusan terhadap tanah yang akan di cabut hak-hak atasnya, terlebih dahulu mesti dilakukan suatu permohonan yang di ajukan kepada yang berkepentingan seperti yang telah tertuang di dalam Pasal 2 UU nomor 20 tahun 1961.

Dan dasar pokok dari UU No 20 tahun 1961 tentang pencabutan hak atas tanah itu adalah ketentuan Pasal 18 UU No. 5 tahun 1960 (UUPA) yang menggariskan untuk kepentingan umum negara dapat melakukan pencabutan hak atas tanah. Pada Pasal 18 UUPA tersebut selengkapnya sebagai berikut "untuk kepentingan umum, termasuk kepentingan bersama dari rakyat hak-hak atas tanah dapat dicabut dengan memberi ganti kerugian yang layak dan menurut cara yang diatur dengan undang-undang"

Untuk melaksanakan ketentuan Pasal 18 UUPA tentang Ontiegening tersebut dituntut persayaratan tegas dan ketat sebagai berikut:

1) Pencabutan hak hanya dapat dilaksanakan bilamana kepentingan umum benar-benar menghendaki. Unsur kepentingan umum ini harus tegas menjadi dasar dalam pencabutan hak ini.

2) Sesuai dengan ketentuan UU No. 20 tahun 1961 pencabutan hak atas tanahnya dapat dilakukan atas izin presiden. 
3) Pencabuatan hak atas tanah tersebut harus di sertai ganti rugi yang layak.

Pencabutan hak yang dilakukan oleh pemerintah tanpa mengindahkan persyaratan tersebut adalah merupakan perbuatan melanggar hukum atau menyalahgunakan wewenang oleh pemerintah.

Sehubungan dengan itu ditentukan pula, bahwa jika telah dilakukan pencabutan hak tetapi kemudian ternyata bahwa tanah dan/atau benda-benda yang bersangkutan tidak dipergunakan sesuai dengan rencana semula yang mengharuskan dilakukannya pencabutan hak itu, maka para bekas pemiliknya diberi prioritas utama untuk mendapatkannya kembali.

Sesuai dengan ketentuan Pasal 58 maka dengan telah mulai berlakunya Undang-Undang Nomor 20 Tahun 1961 tentang Pencabutan Hak-Hak Tanah Dan Benda Yang Ada Di Atas Nya sebagai peraturan pelaksanaan dari Pasal 18 Ontegienings Ordonantie 1920 maka dengan sendirinya tidak berlaku lagi terhadap pencabutan hak atas tanah dan benda-benda lain yang ada di atasnya, tetapi masih berlaku terhadap pencabutan hak atas benda-benda yang tidak termasuk golongan itu (dulu disebut benda-benda bergerak).

Dalam pada itu pembentuk Undangundang berpendapat, bahwa dalam keadaan biasa tidak dirasakan adanya keperluan untuk melakukan pencabutan hak atas benda-benda bergerak tersebut. Sedangkan acara pembebasan hak, kalau dilihat dari yang memiliki ia melepaskan hak kepada negara untuk kepentingan pihak kedua yaitu pembeli dilihat dari yang memerlukan tanah, ia membebaskan hak. Yang dimaksud dengan pembebasan tanah ialah melepaskan hubungan yang semula diantara pemegang hak atau penguasa atas tanahnya dengan cara membe rikan ganti rugi. Hal ini diatur di dalam PMDN nomor 15 tahun 1975. Kita mengetahui bahwa setiap hak atas tanah dapat diserahkan secara suka rela kepada negara dan penyerahan inilah yang disebut pelepasan hak.

Pada hakekatnya penggusuran dalam arti di atas adalah suatu pencabutan hak terselubung. Praktek demikian timbul karena acara pencabutan hak berdasarkan Undang undang Nomor 20 Tahun 1961 dianggap terlalu lama dan tidak efisien. Sebagaimana dijelaskan dalam acara pencabutan hak, banyak instansi yang turut campur, bahkan juga Presiden.

Pembebasan tanah untuk kepentingan swasta pada azasnya harus dilakukan secara langsung antara pihak-pihak yang berkepentingan dengan pemberian ganti rugi dengan berpedoman kepada azas musyawarah. Pada prinsipnya acara pembebasan tanah untuk kepentingan swasra sama dengan acara pembebasan untuk kepentingan pemerintah. Perbedaanya adalah bahwa untuk kepentingan swasta tidak wajib melalui panitia, tentang bila di perlukan dapat pula dimintakan bantuan 
panitia. Dalam hal ini panitia dimaksud bertugas untuk:

a. Mengadakan inventarisasi serta penelitian setempat terhadap keadaan tanahnya, tanaman dan bangunanbangunan.

b. Mengadakan perundingan dengan para pemegang hak atas tanah dan bangunan/tanaman.

c. Menaksir besarnya ganti rugi yang akan di bayarkan ke pada yang berhak.

d. Membuat berita acara pembebasan tanah disertai pembangunan.

e. Menyaksikan pelaksanaan pembayaran ganti rugi kepada yang berhak atas tanah tersebut.

Hal ini tercantum di dalam di dalam

Pasal 3 PMDN nomor 15 tahun 1976. Acara pembebasan hak harus dibuktikan secara tertulis, tetapi tidak di tuntut adanya akta autentik. Dapat di buat pernyataan sepihak dari yang mempunyai tanah atau berupa persetujuan ke dua belah pihak (yang membebaskan dan yang melepaskan).Bentuk akta, tersebut boleh di bawah tangan, boleh pula dengan akte notaris. Di dalam akte bawah tangan harus di kuatkan oleh kepala desa dan camat setempat atau dilegalisasi oleh camat.

Apakah PPAT berwenang membuat akta pelepasan hak, tentu jawabnya adalah tidak, sebab pelepasan hak tidak tercakup dalam akta yang dimaksud dalam Pasal 19 PP Nomor 10 Tahun 1961. Tetapi notaris dan juga PPAT bewenang membuat akte pelepasan hak, tetapi dalam kedudukannya sebagai Notaris bukan sebagai PPAT. Pembuatan melepaskan hak itu dapat pula di lakukan di depan kantor Agraria (BPN) setempat yang akan membuat aktanya dalam kedudukan itu. Hal yang demikian lebih-lebih di perlukan jika tanah yang bersangkuat an belum ada hak tanahnya.Belum ada buku tanahnya berarti status pemiliknya belum mempunyain kepastian. Hal ini akan lebih aman jika akta pelepasanya di buat di depan instansi agraria, sebab kalau tidak ada yang tidak beres dapat di koreksi oleh pejabat itu.

Kalau aktanya tidak di buat dihadapan kepala kantor agraria setempat, misalnya dibuat oleh notaris, maka sebaiknya lebih dahulu dihubungi instansi agraria yang bersangkutan dan dimana keterangan tentang planologi setempat. Berdasarkan penjelasan dari pejabat kantor badan pertahanan Kabupaten Sumenep maka bilamana terjadi pembebasan hak di daerah ini. Maka prosedurnya adalah seperti apa yang telah di uraikan oleh penulis di atas. Dan kemudian bahwa pelaksanaan fungsi sosial di daerah Kabupaten Sumenep pada umumnya masih dalam tahap-tahap pembebasan tanah untuk kepentingan pemerintah sebagai sarana dalam melaksanakan pembangunan yang bertujuan untuk mensejahterakan rakyat di daerah Kabupaten Sumenep ini khususnya.

Sertifikat adalah surat tanda bukti hak sebagaimana dimaksud dalam Pasal 19 Ayat 
(2) huruf c UUPA untuk hak atas tanah, hak pengelolaan, tanah wakaf, hak milik atas satuan rumah susun dan hak tanggungan yang masing-masing sudah dibukukan dalam buku tanah yang bersangkutan. Sebagaimana telah diuraikan diatas bahwa sertifikat tanah adalah salinan buku tanah dan surat ukur yang telah dijilid menjadi satu dengan suatu kertas sampul yang bentuknya ditentukan oleh Menteri Dalam Negeri/Dirjen Agraria dan diberikan kepada seseorang atau badan hukum yang mempunyai hak atas tanah sebagai alat bukti yang kuat. Hal ini mengandung pengertian bahwa keterangan yang tercantum dalam sertifikat sepanjang tidak ada alat bukti yang dapat membuktikan sebaliknya (ketidak benaran), maka keterangan-keterangan tersebut memiliki kekuatan hukum yang harus diterima oleh pihak Pengadilan sebagai suatu keterangan yang benar.

Seiring dengan bertambahnya kegiatan dalam bidang ekonomi di Indonesia, maka bertambah pula kegiatan di bidang perkreditan, karena pada umumnya seorang pengusaha tidak sepenuhnya menyediakan modal untuk usahanya, sehingga diperlukan pinjaman dari luar. Seorang kreditur dalam memberikan pinjaman membutuhkan jaminan jadi mereka tidak akan mengalami kerugian apabila debitur tidak dapat memenuhi kewajibannya di kemudian hari. Apalagi di daerah Kalianget yang sebagian besar masyarakatnya bermata pencaharian sebagai petani garam yang penghasilan setiap bulannya tidak tetap, mereka memerlukan dana untuk menggarap lahannya jadi jalan keluarnya adalah dengan meminjam dana dari bank. Untuk meminjam dana tersebut mereka menjaminkan sertifikat tanahnya, tapi tentunya hanya bagi mereka yang sudah mendaftarkan tanahnya.

Pada umumnya, masyarakat di Kalianget menganggap tanah sebagai jaminan yang aman, bukan saja karena tanah tidak mudah hilang dan musnah, tetapi karena nilai tanah yang cenderung meningkat dari tahun ke tahun apalagi tanah yang sudah bersertifikat harga jualnya akan semakin tinggi di bandingkan dengan tanah tang belum bersertifikat. Bahkan di daerah-daerah yang dilakukan pembangunan, nilai tersebut akan semakin tinggi. Sehubungan dengan itu memungkinkan tanah dijadikan jaminan hutang. Jadi pendaftaran hak milik atas tanah berimplikasi terhadap status hukumnya, baik bagi pemegang hak ataupun bagi objek haknya, sehingga mereka mempunyai suatu kekuatan hukum apabila mereka di desak oleh pihak lain yang mengajukan gugatan terhadap status hukum tanahnya ataupun memberi kemudahan untuk pemilik tanah tersebut untuk menjaminkan tanahnya apabila mereka membutuhkan dana untuk usahanya, disamping itu juga harga jual tanahnya akan semakin tinggi.

Didalam Undang-Undang Pokok Agraria asas fungsi sosial atas tanah yaitu asas yang menyatakan bahwa penggunaan tanah tidak boleh bertentangan dengan hak hak orang lain dan kepentingan umum,serta keagamaan. 
Sehingga tidak diperbolehkan jika tanah digunakan sebagai kepentingan pribadi yang menimbulkan kerugian bagi masyarakat. Fungsi sosial hak atas tanah sebagaimana dimaksud Pasal 6 UUPA mengandung beberapa prinsip keutamaan antara lain :

a. Merupakan suatu pernyataan penting mengenai hak-hak atas tanah yang merumuskan secara singkat sifat kebersamaan atau kemasyarakatan hakhak atas tanah menurut prinsip Hukum Tanah Nasional. Dalam Konsep Hukum Tanah Nasional memiliki sifat komunalistik religius, yang mengatakan bahwa seluruh bumi, air, dan ruang angkasa, termasuk kekayaan alam yang terkandung di dalamnya dalam wilayah Republik Indonesia, sebagai karunia Tuhan Yang Maha Esa, adalah bumi, air dan ruang angkasa, bangsa Indonesia dan merupakan kekayaan nasional.

b. Tanah yang dihaki seseorang tidak hanya mempunyai fungsi bagi yang mempunyai hak itu saja tetapi juga bagi bangsa Indonesia seluruhnya. Sebagai konsekuensinya, dalam mempergunakan tanah yang bersangkutan tidak hanya kepentingan individu saja yang dijadikan pedoman, tetapi juga harus diingat dan diperhatikan kepentingan masyarakat. Harus diusahakan adanya keseimbangan antara kepentingan pribadi dan kepentingan masyarakat.

c. Fungsi sosial hak-hak atas tanah mewajibkan pada yang mempunyai hak untuk mempergunakan tanah yang bersangkutan sesuai dengan keadaannya, artinya keadaan tanah, sifatnya dan tujuan pemberian haknya. Hal tersebut dimaksudkan agar tanah harus dapat dipelihara dengan baik dan dijaga kualitas kesuburan serta kondisi tanah sehingga kemanfaatan tanahnya dinikmati tidak hanya oleh pemilik hak atas tanah saja tetapi juga masyarakat lainya. Oleh karena itu kewajiban memelihara tanah itu tidak saja dibebankan kepada pemiliknya atau pemegang haknya yang bersangkutan, melainkan juga menjadi beban bagi setiap orang, badan hukum atau instansi yang mempunyai suatu hubungan hukum dengan tanah.

Undang-Undang Pokok Agraria menjamin hak milik pribadi atas tanah tersebut tetapi penggunaannya yang bersifat untuk kepentingan pribadi maupun kelompok tidak boleh bertentangan dengan kepentingan masyarakat.Sehingga timbul keseimbangan, kemakmuran, keadilan, kesejahteraan bagi masyarakat maupun pribadi yang memiliki tanah.Jadi pemilik tanah tidak akan kehilangan haknya dalam memiliki tanah akan tetapi dalam pelaksanaan untuk kepentingan umum maka haknya akan berpindah untuk kepentingan umum.

\section{PENUTUP}

Pelaksanaan Fungsi Sosial Hak Atas Tanah di PT. Garam (Persero) Sumenep, 
pencabutan hak atas tanah merupakan suatu sarana yang diselenggarakan oleh pemerintah untuk mengambil hak atas tanah warga negara demi kepentingan umum, yang di dalamnya terdapat kepentingan bersama rakyat, kepentingan bangsa dan negara, serta kepentingan pembangunan. Tercantum dalam Pasal 1 UU Nomor 20 tahun 1961 tentang Pencabutan Hak-Hak Tanah Dan Benda Yang Ada Di Atas Nya. Undang-Undang Pokok Agraria asas fungsi sosial atas tanah yaitu asas yang menyatakan bahwa penggunaan tanah tidak boleh bertentangan dengan hak hak orang lain dan kepentingan umum,serta keagamaan. Sehingga tidak diperbolehkan jika tanah digunakan sebagai kepentingan pribadi yang menimbulkan kerugian bagi masyarakat. Dalam Konsep Hukum Tanah Nasional memiliki sifat komunalistik religius, yang mengatakan bahwa seluruh bumi, air, dan ruang angkasa, termasuk kekayaan alam yang terkandung di dalamnya dalam wilayah Republik Indonesia, sebagai karunia Tuhan Yang Maha Esa, dan merupakan kekayaan nasional. Tanah yang dihaki seseorang tidak hanya mempunyai fungsi bagi yang mempunyai hak itu saja tetapi juga bagi bangsa Indonesia seluruhnya. Sebagai konsekuensinya, dalam mempergunakan tanah yang bersangkutan tidak hanya kepentingan individu tetapi juga kepentingan masyarakat. Harus adanya keseimbangan antara kepentingan pribadi dan kepentingan masyarakat. Fungsi sosial hak-hak atas tanah mewajibkan pada yang mempunyai hak untuk mempergunakan tanah yang bersangkutan sesuai dengan keadaannya, dimaksudkan agar tanah harus dapat dipelihara dengan baik dan dijaga kualitas kesuburan serta kondisi tanah sehingga kemanfaatan tanahnya dinikmati tidak hanya oleh pemilik hak atas tanah saja tetapi juga masyarakat lainya. Oleh karena itu kewajiban memelihara tanah itu tidak saja dibebankan kepada pemiliknya atau pemegang haknya yang bersangkutan, melainkan juga menjadi beban bagi setiap orang, badan hukum atau instansi yang mempunyai suatu hubungan hukum dengan tanah.

\section{DAFTAR PUSTAKA}

Chomzah, Ali Achmad. Hukum Pertanahan; Pemberian Hak atas Tanah Negara, Sertipikat dan Permasalahan, Jakarta : Prestasi Pustaka, 2002.

Muhammad, Abdulkdir. 2004, Hukum dan Penelitian Hukum, Citra Aditya Bakti, Badung.

Harsono, Boedi. Hukum Agraria Indonesia, Sejarah Pembentukan UndangUndang Pokok Agraria, Isi dan Pelaksnaannya, Jilid I. Jakarat : Djambatan, 2003.

Muljadi, Kartini,dkk. 2004. Hak-Hak Atas Tanah. Jakarta: Kencana.

Suhadi dan Wahasisa, Rofi. Buku Ajar Pendaftaran Tanah, Semarang : Universitas Negeri Semarang, 2008.

Supriadi, Hukum Agraria, Jakarta : Sinar Grafika, 2007. 
Santoso, Urip. Hukum Agraria Kajian Komprehensif, Jakarta : Kencana, 2012.

Undang-Undang Nomor 5 Tahun 1960 tentang Peraturan Dasar PokokPokok Agraria (UUPA).

Undang-Undang Nomor 20 tahun 1961 tentang Pencabutan Hak-Hak Tanah Dan Benda Yang Ada Di Atas Nya.

Peraturan Pemerintah Nomor. 40 Tahun 1996 tentang Hak Guna Usaha, Hak Guna Bangunan dan Hak Pakai Atas Tanah.

Peraturan Mentri Dalam Negeri Nomor 15 tahun 1975 tentang Ketentuanketentuan Mengenai Tata Cara. Pembebasan Tanah.

Peraturan Pemerintah Nomor. 24 Tahun 1997, tentang Pendaftaran Tanah. 